\title{
Role of Farmer Groups and Field Agricultural Extension Officer in the Development of Organic Rice Agricultural Institutions in Boyolali Regency, Indonesia
}

\author{
Ignatius Suprih Sudrajat \\ Department of Agribusiness, Agriculture Faculty, University of Sarjanawiyata Tamansiswa, Jl. Batikan No. 06 \\ Tahunan, Umbulharjo, Post Code: 55167, Yogyakarta, Indonesia.
}

\begin{abstract}
This research is a study that aims to analyze the role of farmer groups and field agricultural extension officer in the development of organic rice farming institutions. This study was carried out mostly in two farmer groups, namely: Pangudi Boga and Pangudi Raharjo in Dlingo Village, Mojosongo District, Boyolali Regency, Central Java Province, Indonesia with a total sample of 216 organic certified national rice farmers and an internal control system chosen from 521 population with a purposive sampling method. To see the influence of the role of farmer groups and field agricultural extension officer on the production cost efficiency of organic rice farming, a stochastic frontier approach with cross section data is used, and then the data is estimated using Maximum Likelihood Estimation. The results of this study are variable of the role of farmer groups and field agricultural extension officer is the dominant variables that influence the inefficiency of production cost with a coefficient value of -0.5497 . In terms of agricultural institutions, in this case the role of farmer groups and field agricultural extension officers can be seen that all respondent farmers (100\%) are members of farmer groups and have become members of agricultural associations as much as $96.30 \%$. Agricultural association institutions that are mostly followed by farmers are farmer groups, namely $91.10 \%$. Field agricultural extension officer is also very important, proven that $95.40 \%$ are chosen and trusted by farmers as facilitators who assist farmer groups in improving their organic rice farming in the form of agricultural institutional development.
\end{abstract}

Keywords: Farmer groups, Agricultural institutions, Organic rice farming, Stochastic frontier, Boyolali

DOI: $10.7176 / \mathrm{JBAH} / 10-2-06$

Publication date: January $31^{\text {st }} 2020$

\section{Introduction}

Rice is the world's most important crop. It has supported more people for more years than any other cereal. The great civilizations of Asia emerged in the broad river deltas of China, Southeast Asia and the Indian subcontinent because high yields of rice sufficient to support more than the food demands of those who produced it could be sustained. The important of rice in Asia is such that it has become deeply entwined with the cultures of the region. The terraced systems by which water is channeled to the small fields in which rice is grown have characterized the Asian landscapes for many years (Greenland 1997).

To be able to cultivate healthy and environmentally friendly rice plants, it is necessary to develop an organic farming system that is environmentally friendly. Organic farming system is one of the solutions to solve the classic problem in the world of agriculture. Organic farming can be said to be an agricultural process that utilizes nature and the surrounding environmental conditions. International Federation Organic Agricultural Movement (IFOAM) explained that organic agriculture is a production system that sustains the health of soils, ecosystems and people. It relies on ecological processes, biodiversity and cycles adapted to local conditions, rather than the use of inputs with adverse effects. Organic agriculture combines tradition, innovation and science to benefit the shared environment and promote fair relationships and a good quality of life for all involved (Kristiansen et al. 2006).

Organic farming began to be developed by farmers in Indonesia after the era of green revolution technology. The green revolution which initially brought a dramatic increase in agricultural output is now beginning to be felt to have a negative impact. Rice production began to decline due to the use of chemical fertilizers and pesticides during the green revolution since 1963 until now. Soil fertility decreases, therefore efforts are needed to increase land productivity and soil conservation through organic agriculture. The philosophy of organic agriculture is actually a moral appeal to do good in the environment of natural resources in carrying out agricultural practices by considering three aspects, namely economic, social and environmental aspects (Sudrajat 2018).

To be able to produce healthy organic food products, there needs to be awareness from farmers to start organic rice cultivation. That awareness can be manifested in togetherness as a group or community (Guzmán \& Alonso 2010) that really tries to cultivate organic rice, for example through farmer groups or farmer groups in villages or districts and also through field extension activities. Efforts to prioritize the role of farmer groups and field extension activities are in line with the policies carried out by the government through the launching of 
agriculture, fisheries and forestry revitalization 2005-2025 and Law of the Republic of Indonesia Number 16 of 2006 concerning agricultural extension services, fisheries and forestry. In both of these government policies the problem of agricultural institutions remains an essential part, both agricultural institutions at the macro level, and at the micro level (Badan Litbang Pertanian 2005).

Anggraeni et al. (2015) stated that the farmer group is a forum formed by the local village government in order to become a forum for farmers to be able to run their organic rice farming. The farmer group consists of farmers with all the local wisdom in it. Field agricultural extension officer is a teacher or accompanying instructor whose role is to motivate farmers, especially in the farmer groups themselves in increasing production and farming. Field agricultural extension officer usually conducts agricultural extension services and guidance to farmer groups through meetings held by the farmer group itself. Agricultural extension activities are activities that have clear objectives and must be achieved. Therefore, every implementation of agricultural extension needs to be based on a particular work strategy for its success to achieve the desired goals. The interaction of the farmers with the organic rice farming extension program in Mojosongo District, Boyolali Regency is still quite good, where farmers still have an awareness of the importance of an extension for improving their farming. Good cooperation between farmer groups and field agricultural extension officer will affect the development of agricultural institutions in this area.

This study is a study that aims to analyze the role of farmer groups and field agricultural extension officer in the development of organic rice farming institutions in Mojosongo District, Boyolali Regency, Central Java Province, Indonesia. Many researchers have examined the role of farmer groups and field agricultural extension officer as influential inputs in the technical, allocative and economic efficiency of conventional rice farming, as practiced by (Kalirajan 1984; Kalirajan \& Shand 1989; Utama 2003; Mynt \& Kyi 2005; Idiong 2007; Alemu et al. 2008; Galawat \& Yabe 2012; Lema et al. 2016). However, there are also some researchers who examine the role of farmer groups and field agricultural extension officer as influential inputs in the technical, allocative and economic efficiency of organic or semi-organic rice farming, as practiced by (Prayoga 2010; Murniati et al. 2014; Anggraeni et al. 2015; Sudrajat et al. 2017; Wihastuti et al. 2017; Sudrajat et al. 2018; Hadi et al. 2019; Sudrajat et al. 2019).

\section{Methodology}

\subsection{Research Area and Data Collection}

This research was conducted in Boyolali Regency, Central Java Province, Indonesia, which included five districts (Andong, Nagasari, Sambi, Simo and Mojosongo) and seven villages (Catur, Jatisari, Dlingo, Metuk, Andong, Wates and Glonggong), but were more focused on two farmer groups, namely Pangudi Boga and Pangudi Raharjo in Dlingo Village, Mojosongo District. Boyolali Regency is known as a rice-producing area including organic rice. Data on the area of organic rice commodity certified by the Indonesian Organic Alliance (AOI) states, Boyolali Regency has an area of organic rice of 10.2 hectares of all organic material commodities (vegetables, horticulture, etc.) covering 318.45 hectares (Aliansi Organis Pertanian 2016). This indicates that Boyolali is a place for producing organic food, especially organic rice, which should be taken into account in Indonesia.

Rice farmers in Boyolali Regency are classified into conventional rice farmers, ICS (Internal Control System) certified organic rice farmers and national certified organic rice farmers. Based on data from the Boyolali Organic Rice Farmers Association (Appoli) in 2014, organic rice farmers were divided into rice farmers who transitioned to organic rice, known as ICS and nationally certified farmers. The number of certified farmers is 521 farmers who are also the study population, spread in five districts, namely Sambi District (Catur Village: 72 farmers and Jatisari Village: 60 farmers), Mojosongo District (Dlingo Village: 151 farmers and Metuk Village: 56 farmers ), Andong District, Andong Village: 79 farmers, Simo District, Wates Village: 13 farmers, and Nogosari District, Glonggong Village as many as 30 farmers. From 521 farmers population, 216 organic rice farmers were taken as samples with purposive sampling method.

From five districts, four are rain-fed agriculture (Districts: Andong, Nogosari, Sambi and Simo) and one other district is irrigated agriculture (Mojosongo District). In this study, one district was selected, namely Mojosongo District which is an irrigated organic agriculture with water sources from the spring above, so that all farmers really do organic rice farming. The organic rice farming land which is cultivated occupies a specific location separate from the conventional rice cultivation location (one stretch of organic rice) located in Dlingo Village with two farmer groups, namely the Pangudi Boga farmer group and the Pangudi Raharjo farmer group whose members are quite active.

This research is a qualitative and quantitative research supported by primary and secondary data through indepth interviews with existing farmers and stakeholders. Primary data collection is carried out to capture the characteristics of farm households, land tenure structures, farm household income structures, organic rice farming inputs and socio-economic factors that affect the efficiency of organic rice farming, while secondary data collection includes data from Central Bureau of Statistics (BPS) on growth Indonesian population and rice 
production and growth data. Besides that, it is also equipped with description data of Boyolali Regency and its districts which are related to the development of land area, productivity, and institutional aspects and agricultural management. The tool used to analyze primary data is the stochastic frontier program version 4.1 and the estimator uses Maximum Likelihood Estimation (MLE).

\subsection{Analytical Framework}

Farrell (1957); Coelli et al. (1998) states that efficiency is classified into three, namely technical efficiency (TE), allocative efficiency (AE), and economic efficiency (EE). Technical efficiency (TE) shows the ability of farming to obtain maximum output from a certain number of inputs or in other words, technical efficiency is used to measure the amount of production that can be achieved at a certain level of input. Cost efficiency/ allocative efficiency (AE) is the ability of farmers to use inputs at optimal proportions at factor prices and fixed production technology (given). Cost efficiency shows the relative ability of a farm to use inputs to produce output under conditions of minimal cost or maximum profit at a certain technological level. Yotopaulus \& Nugent (1976) stated that the combination of technical efficiency (TE) and allocative efficiency (AE) would be economic efficiency (EE). Economic efficiency is understood as the ability of farmers to produce to produce a predetermined number of outputs. It means that the products produced both technically and allocatively, are efficient, economically seen as efficient because the combination of input-output will be in the frontier production function and business development path.

Aigner et al. (1977); Meeusen \& Van den Broeck (1977); Jondrow et al. (1982); Coelli (1996) suggested that stochastic frontier function is an extension of the original deterministic models to measure the unpredictable effects in the production limits. In his production function, random error $\left(\mathrm{V}_{\mathrm{i}}\right)$ is added into non-negative random variable $\left(\mathrm{U}_{\mathrm{i}}\right)$. Random error $\left(\mathrm{V}_{\mathrm{i}}\right)$, is useful to calculate the size of the error and other random factors such as weather and others together with the effect of the combination of input variables that are undefined in the production function. Variable $\mathrm{V}_{\mathrm{i}}$ is a random variable that is independent and identically distributed normal (independent identically-distributed) with zero mean and constant variant. Variable $U_{i}$ is assumed as $i$ exponential or half-normal random variable (half-normal variables). If we want to determine the stochastic frontier cost function, we just change the specification of error of $\left(V_{i}-U_{i}\right)$ to $\left(V_{i}+U_{i}\right)$ so that this substitution will alter the production cost function as the following function:

where:

$$
\mathrm{C}_{\mathrm{i}}=\mathrm{X}_{\mathrm{i}} \beta+\left(\mathrm{V}_{\mathrm{i}}+\mathrm{U}_{\mathrm{i}}\right) \quad, \mathrm{i}=1, \ldots, \mathrm{N},
$$

$\mathrm{C}_{\mathrm{i}} \quad=$ production cost of organic rice in natural logarithm (ln)

$\mathrm{X}_{\mathrm{i}} \quad=$ input price normalized with output price in natural logarithm (ln)

$\beta=$ parameter

$\mathrm{V}_{\mathrm{i}} \quad=$ errors caused by factors beyond the farmers'control

$\mathrm{U}_{\mathrm{i}}=$ errors caused by factors under the farmers'control

In the cost function, $U_{i}$ now determine how far farmers operate their farming system above the limit cost. If allocative efficiency is assumed, $U_{i}$ is closely related to the cost of technical inefficiency. If this assumption is not made, the interpretation of $U_{i}$ in the cost function is less clear, with both technical and allocative inefficiency used.

To see the effect of the variables determining the level of production cost inefficiency on organic rice farming system in Mojosongo District, Boyolali Regency, the following formula is used: where:

$$
\mathrm{U}_{\mathrm{i}}=\delta_{0}+\delta_{1} \mathrm{Z}_{1}+\delta_{2} \mathrm{Z}_{2}+\delta_{3} \mathrm{Z}_{3}+\delta_{4} \mathrm{Z}_{4}+\delta_{5} \mathrm{Z}_{5}+\delta_{6} \mathrm{Z}_{6}+\delta_{7} \mathrm{Z}_{7}+\delta_{8} \mathrm{Z}_{8}+\delta_{9} \mathrm{Z}_{9}+\delta_{10} \mathrm{Z}_{10}
$$

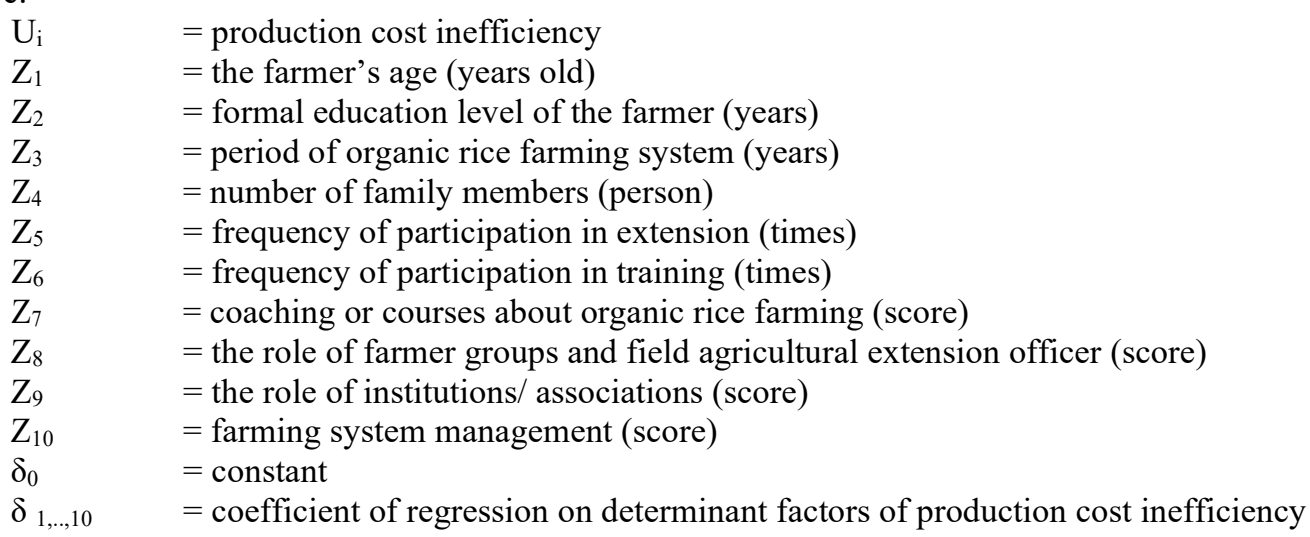

\subsection{Hypothesis}

Testing a hypothesis on the variables that influence the production cost inefficiency can be formulated as follows: 
$\mathrm{H}_{0}: \delta_{\mathrm{i}}=0$ : If $\mathrm{t}_{\text {count }}<\mathrm{t}_{\text {table, }}$, then $\mathrm{H}_{0}$ was accepted $\left(\mathrm{H}_{1}\right.$ rejected). It means that the variables did not influence the production cost inefficiency of organic rice farming in Boyolali Regency, Indonesia.

$\mathrm{H}_{1}: \delta_{\mathrm{i}} \neq 0$ : If $\mathrm{t}_{\text {count }}>\mathrm{t}_{\text {table, }}$, then $\mathrm{H}_{0}$ was rejected $\left(\mathrm{H}_{1}\right.$ accepted). It means that the variables influenced the production cost inefficiency of organic rice farming in Boyolali Regency, Indonesia.

\section{Results and Discussion}

3.1 Role of Farmer Groups and Field Agricultural Extension Officer as a Dominant Variable

There are several factors predicted to be the cause of the inefficiency of the production cost of organic rice farming, including: farmers' age; formal education level of farmers; organic rice farming period; number of farmers' family members; frequency of participation in extension; frequency of participation in training; courses about organic rice farming; role of farmer groups and field agricultural extension officer; role of institutions or associations; and farming system management on organic rice farming. From the estimation results it can be seen that the third most influential variable on the production cost inefficiency of organic rice farming is the variable of courses about organic rice farming with a coefficient value of -0.2927 , the second most influential variable on the production cost inefficiency of organic rice farming is the farming system management variable with a coefficient value of -0.4409 , and the most dominant variable affecting the production cost inefficiency of organic rice farming is the variable of role of farmer groups and field agricultural extension officer with a coefficient value of -0.5497 . It indicates that if the influential variables are increased, the production cost inefficiency of organic rice will decrease. It can be seen on Table 1 below:

Table 1. Estimation result of variables affect production cost inefficiency

\begin{tabular}{lcccc}
\hline \multicolumn{1}{c}{ Variable } & Parameter & $\begin{array}{c}\text { Coefficient of } \\
\text { regression }\end{array}$ & $\begin{array}{c}\text { Standard } \\
\text { error }\end{array}$ & $\begin{array}{c}\text { t- } \\
\text { count }\end{array}$ \\
\hline Constant & $\mathrm{Z}_{0}$ & $-0.1249^{* * *}$ & 0.0274 & -4.383 \\
Farmers age & $\mathrm{Z}_{1}$ & $0.0009^{* * *}$ & 0.0023 & 4.125 \\
Formal education level of farmers & $\mathrm{Z}_{2}$ & $-0.0421^{* * *}$ & 0.0067 & -6.268 \\
Organic rice farming period & $\mathrm{Z}_{3}$ & $0.1092^{\mathrm{NS}}$ & 0.1584 & 0.689 \\
Number of farmers' family members & $\mathrm{Z}_{4}$ & $-0.1376^{\mathrm{NS}}$ & 0.2295 & -0.599 \\
Frequency of participation in extension & $\mathrm{Z}_{5}$ & $-0.1255^{* * *}$ & 0.0193 & -6.391 \\
Frequency of participation in training & $\mathrm{Z}_{6}$ & $0.0273 \mathrm{NS}$ & 0.0628 & 0.434 \\
Courses about organic rice farming & $\mathrm{Z}_{7}$ & $-0.2927^{* * *}$ & 0.0496 & -5.898 \\
Role of farmer groups and field & $\mathrm{Z}_{8}$ & $-0.5497^{* * *}$ & 0.0921 & -5.597 \\
agricultural extension officer & $\mathrm{Z}_{9}$ & $-0.0495^{* *}$ & 0.0214 & -2.317 \\
Role of institutions/ associations & $\mathrm{Z}_{10}$ & $-0.4409 * * *$ & 0.1458 & -3.024 \\
Farming system management & & &
\end{tabular}

Source: Analysis of Primary Data, 2016

Note:

$\begin{array}{rllll}* * * & = & \text { significant at } \alpha=1 \% & \text { t-table } 1 \% & =2,358 \\ * *= & \text { significant at } \alpha=5 \% & \text { t-table } 5 \% & =1,980 \\ *= & \text { significant } \quad \text { at } & \text { t-table } 10 \% & =1,658 \\ & \alpha=10 \% & & \\ \text { NS }= & \text { non significant at } & & \\ & \alpha=10 \% & & \end{array}$

From the data of variables that influence the inefficiency of organic rice production costs, it can be seen that the variable of the role of farmer groups and field agricultural extension officer is the most significant variable affecting the production cost inefficiency of organic rice farming. The role of farmer groups and field agricultural extension officer in reducing the production cost inefficiency of organic rice farming in Boyolali Regency is inseparable from the collaboration of farmers and field agricultural extension officer in developing organic farming institutions in Boyolali Regency, especially in Mojosongo District with its two farming groups, namely Pangudi Boga and Pangudi Raharjo. With good cooperation from farmer groups and field agricultural extension officer can provide enthusiasm, insight and new perspectives for organic rice farmers to further improve the productivity of organic rice and reduce the inefficiency of existing production costs, so as to contribute to healthy food for the community.

\subsection{Role of Farmer Groups in the Development of Agricultural Institutions}

Agricultural institution is the basis for the formation of socio-economic capital that can facilitate cooperation in organic rice farming activities. Scott (2008) defines the conception of agricultural institutions which includes: regulative, normative and cognitive-cultural elements that synergize side by side with activities and resources that provide stability and give meaning to the socio-economic life of the community. Institutional support in the development of organic rice farming has an important role in every activity of each farmer group in it. Farmer's 
social capital which includes a network of cooperation, mutual trust in cooperation, and norms of cooperation in an organic farming system will affect the success of organic rice agribusiness. The existence of farmer institutions such as farmer groups can motivate their members to adopt new technologies. Farmer groups are seen as a unit of study that has its own soul, there are four aspects that can be learned to find out institutional motivation, namely institutional history, the mission it carries, the culture that holds on to behave and behave in its members, as well as the pattern of rewards adopted or incentive schemes (Nuraini et al. 2016).

Agricultural institution is a good entrance to be able to see other institutional aspects in which there is institutional performance. Institutional performance consists of: institutional effectiveness in achieving its goals, efficient use of resources, and institutional sustainability in interacting with other interest groups. The role of farmer groups and field agricultural extension officers make a good contribution to the development of neighboring farmer groups to jointly work on organic rice farming. Discussions on the role of farmer groups and field agricultural extension officer can be seen in Table 2. It shows that all respondent farmers $(100 \%)$ are members of farmer groups and $99.10 \%$ of farmer group members hold regular meetings in their groups with attendance of $70.40 \%$. There are still $29.60 \%$ of farmers who are absent and if the presence of farmers can be increased, then counseling conducted by farmer groups and field agricultural extension officer can be more effective and beneficial for farmers. From Table 2 it can be seen that the role of field agricultural extension officer as a field facilitator for farmers is quite significant, which is $95.40 \%$ compared to the local village office $(0.10 \%)$ or the head of the farmer group $(4.50 \%)$. This indicates that farmers' trust in the performance of field agricultural extension officer is still very high. Field agricultural extension officer has many roles to assist farmers in efforts to increase productivity and quality of organic rice farming in Mojosongo District, Boyolali Regency.

Table 2. Description of the role of farmer groups and field agricultural extension officer

\begin{tabular}{|c|c|c|}
\hline \multirow[t]{2}{*}{ List of information } & \multicolumn{2}{|c|}{$\begin{array}{l}\text { Farmer response } \\
\qquad(\%)\end{array}$} \\
\hline & Yes & No \\
\hline Farmers become members of farmer groups & 100.00 & 0.00 \\
\hline Regular meetings in groups & 99.10 & 0.90 \\
\hline Farmers are always present at the meeting & 70.40 & 29.60 \\
\hline \multicolumn{3}{|l|}{ Material discussed in group meetings: } \\
\hline Agricultural cultivation techniques & 88.00 & 12.00 \\
\hline Marketing of agricultural products & 74.10 & 25.90 \\
\hline Farmer groups conditions & 86.10 & 13.90 \\
\hline Circumstances of the surrounding community & 49.10 & 50.90 \\
\hline \multicolumn{3}{|l|}{ Facilitators who often provide counseling to farmers: } \\
\hline Field agricultural extension officer & \multicolumn{2}{|c|}{95.40} \\
\hline Village officials & \multicolumn{2}{|c|}{0.10} \\
\hline The chairman of farmer groups & \multicolumn{2}{|c|}{4.50} \\
\hline \multicolumn{3}{|l|}{ Extension institutions that are widely known by farmers: } \\
\hline Agricultural Extension Center & \multicolumn{2}{|c|}{8.10} \\
\hline Agricultural Extension Information Center & \multicolumn{2}{|c|}{1.80} \\
\hline Farmer groups & \multicolumn{2}{|c|}{90.10} \\
\hline $\begin{array}{l}\text { Farmer groups in one area help one another in managing farms on the farms of } \\
\text { group members (plowing rice fields, water management, planting, etc.) }\end{array}$ & 94.40 & 5.60 \\
\hline
\end{tabular}
Source: Analysis of Primary Data, 2016

The organic rice farmers in Mojosongo District, Boyolali Regency were surveyed as samples other than as members of farmer groups, they were also members of associations $(96.30 \%)$. The associations in Mojosongo District, Boyolali Regency are Village Unit Cooperative or Koperasi Unit Desa (KUD), farmer groups association (Gapoktan) and farmer groups. There are $91.10 \%$ of farmers that member of farmer groups. The others are members of KUD (2.40\%) and farmer groups association (7.50\%). From Table 3 it can be seen that the efforts of farmers in developing agricultural institutions are still minimal. There are many factors that make farmers less enthusiastic in routine meetings (only $68.50 \%$ are present and $21.30 \%$ are always present at association meetings). In every activity of the association, $50.90 \%$ of active farmers can also be seen. 
Table 3. Description of the role of institutions/ associations

\begin{tabular}{lcc}
\multicolumn{1}{c}{ List of information } & \multicolumn{2}{c}{ Farmer response (\%) } \\
\cline { 2 - 3 } & Yes & No \\
\hline Farmers become members of the association & 96.30 & 3.70 \\
Regular meetings in association & 68.50 & 31.50 \\
Farmers are always present at the meeting in association & 21.30 & 78.70 \\
Material discussed in association: & 63.00 & 37.00 \\
Agricultural cultivation techniques & 50.90 & 49.10 \\
Marketing of agricultural products & 43.60 & 56.40 \\
Farmer groups conditions & 18.50 & 81.50 \\
Circumstances of the surrounding community & 46.30 & 53.70 \\
In association meetings, participating farmers expressed their opinions & 38.00 & 62.00 \\
Farmers are involved in decision making in associations & 50.90 & 49.10 \\
Farmers are active in association activities & & 2.40 \\
Many associations that are followed by farmers: & & 7.50 \\
Village Unit Cooperative (KUD) & & 91.10 \\
Farmer groups association (Gapoktan) & & \\
Farmer groups & & \\
\hline
\end{tabular}

Source: Analysis of Primary Data 2016

In the development of agricultural institutions, there are elements outside the non-technical farming system that are decisive (Kusnandar et al. 2018) for example: structural agricultural institutions, culture and agricultural values that are unique to the area. The condition of the community as farmers who have local wisdom and hereditary habits are indeed not easy to change. There are several things that must be considered to be able to develop agricultural institutions, namely (i) avoid building institutions that are limited to strengthening horizontal ties, (ii) institutions are built not to channel aid only, but also as social economic capital, (iii) after being formed, institutional development must not be individual, but togetherness, (iv) institutional elements should strengthen the elements of local wisdom that existed before and not tearing down (Syahyuti 2004). If the awareness of farmers and stakeholders has emerged and is determined to develop agricultural institutions, this will undoubtedly be a powerful driving force and extraordinary socio-economic capital for the improvement of organic rice farming in Boyolali Regency and for the welfare of the community going forward.

\section{Conclusion}

Agricultural institution is not just a set of rules that regulates or binds and is obeyed by its members. The conception of agricultural institutions includes regulative, normative, and cognitive-cultural elements that synergize side by side in the life of the farming community. Agricultural institution in Mojosongo District, Boyolali Regency is built from the role of active and caring farmer groups and field agricultural extension officer to develop existing agricultural institutions, so that later it can increase the productivity of organic rice farming. The most dominant variable affecting the production cost inefficiency of organic rice farming is the variable of role of farmer groups and field agricultural extension officer with a coefficient value of -0.5497 . It indicates that if the influential variables are increased, the production cost inefficiency of organic rice will decrease.

The role of farmer groups in developing organic farming institutions is very evident from the data that $100 \%$ of the members are members of farmer groups and $96.30 \%$ as members of institutional associations, and from $96.30 \%$ of these members, $91.10 \%$ are members of farmer groups that are quite active in conducting routine meetings $(68.50 \%)$ in the farming groups. Besides that, the role of field agricultural extension officer is also very important, proven that $95.40 \%$ are chosen and trusted by farmers as facilitators who assist farmer groups in improving their organic rice farming in the form of agricultural institutional development. Thus it can be said that the enthusiasm of farmers to become members of farmer groups is still quite high. This is also thanks to the assistance of field agricultural extension officer who is always present to help farmers to be able to actively participate as members of farmer groups in running their organic rice farming. The role of farmer groups and field agricultural extension officer has been proven to reduce the production cost inefficiency of organic rice farming in Mojosongo District, Boyolali Regency, Indonesia.

\section{References}

Aigner, D.J., Lovell, C.A.K., \& Schmidt, P. (1977), "Formulation and Estimation of Stochastic Frontier Production Function Model", Journal of Econometrics 6(1), 21-37. [Online] Available: https://pdfs.semanticscholar.org/3d6c/a6a699e579463e0b01526d9842d41f26b314.pdf

Alemu, B.A., Nuppenau, E.A., \& Boland, H. (2009), “Technical Efficiency Across Agro-Ecological Zones in Ethiopia: The Impact of Poverty and Asset", Agricultural Journal 4(4), 202-207. [Online] Available: 
http://medwelljournals.com/abstract/?doi=aj.2009.202.207

Aliansi Organis Pertanian (2017), "Statistik Pertanian Organik Indonesia 2016 [Statistics of Indonesia's Organic Agriculture 2016]", Bogor: Aliansi Organis Indonesia.

Anggraeni, R., Dumasari, D., \& Utami, P. (2015), "Kajian interaksi sosial penyuluh pertanian dengan petani padi semi organik kelompok tani Jatijaya Desa Sawangan, Kecamatan Kebasen, Kabupaten Banyumas [Study of social interaction of agricultural instructors with semi-organic rice farmers Jatijaya farmer groups Sawangan Village, Kebasen District, Banyumas Regency]", Agritech 17(2), 144-155. DOI: 10.30595/agritech.v17i2.1730

Badan Litbang Pertanian (2005), "Revitalisasi Pertanian, Perikanan dan Kehutanan 2005-2025 [Revitalizing Agriculture, Fisheries and Forestry 2005-2025]", [Online] Available: http://www.litbang.deptan.go.id/rppk

Coelli, T.J. (1996), "A Guide to Frontier Version 4.1.: A Computer Program for Stochastic Frontier Production and Cost Function Estimation", CEPA Working Papers No. 7/96. Armidale: Department of Econometrics, University of New England. [Online] Available: http://www.une.edu.au/econometrics/cepa.htm

Coelli, T.J., Rao, D.S.P., O’Donnell, C.J., \& Battese, G.E. (1998), “An Introduction to Efficiency and Productivity Analysis", London: Kluwer Academic Publishers.

Farrell, M.J. (1957), “The Measurement of Productive Efficiency”, Journal of the Royal Statistics Society 120(3), 253-290. DOI: $10.2307 / 2343100$.

Galawat, F. \& Yabe, M. (2012), "Evaluation of Technical, Allocative and Economic Efficiency in Rice Production: A Case Study on Rice Farmers in Brunei Darussalam", Journal of Faculty of Agriculture, Kyushu University 57(1), 317-325. [Online] Available: https://www.researchgate.net/publication/221676613 Evaluation of Technical Allocative and Economic Efficiency in Rice_Production_A_Case_Study_on_Rice_Farmers_in_Brunei_Darussalam/link/56c6c65d 08ae03b93ddae484/download

Greenland, D.J. (1997), “The Sustainability of Rice Farming”, Wallingford, UK: CAB International.

Guzmán, G.I. \& Alonso, A.M. (2010), "The European Union: Key Roles Institutional Support and Economic Factors", In: Gliessman, S.R. \& Rosemeyer, M. (eds). "The Conversion to Sustainable Agriculture Principles, Processes, and Practices", Boca Raton, London, New York: CRC Press Taylor \& Francis Group.

Hadi, S., Akhmadi, A.N., \& Prayuginingsih, H. (2019), "Peran Kelompok Tani dan Persepsi Petani terhadap Penerapan Budidaya Padi Organik di Kabupaten Jember [Role of Farmer Groups and Farmers' Perception in Promoting its Members Against Application of Organic Rice Cultivation in Jember Regency]", Jurnal Penyuluhan 15(2), 154-168. DOI: https://doi.org/10.25015/penyuluhan.v15i2.18492

Idiong, I.C. (2007), "Estimation of Farm Level Technical Efficiency in Small Scale Swamp Rice Production in Cross River State of Nigeria: A Stochastic Frontier Approach", World Journal of Agricultural Sciences 3(5), 653-658. [Online] Available: https://www.researchgate.net/publication/241482594_Estimation_of_Farm_Level_Technical_Efficiency_in Smallscale Swamp Rice Production in Cross River State of Nigeria A Stochastic Frontier Approac $\mathrm{h}$

Jondrow J., Lovell, C.A.K., Materov, I.S., \& Schmidt, P. (1982), “On the Estimation of Technical Inefficiency in the Stochastic Frontier Production Function Model", Journal of Econometrics 19(2\&3), 233-238. DOI: 10.1016/0304-4076(82)90004-5.

Kalirajan, K.P. (1984), "Farm-Specific Technical Efficiencies and Development Policies", Journal of Economic Studies 11(3), 3-13. DOI: https://doi.org/10.1108/eb002579

Kalirajan, K.P. \& Shand, R.T. (1989), “A Generalized Measure of Technical Efficiency”, Pakistan Journal of Applied Economics 21(1), 25-34. DOI: https://doi.org/10.1080/772284229

Kristiansen, P., Taji, A. \& Reganold, J. (eds.) (2006), "Organic Agriculture: A Global Perspective", Collingwood, Victoria: CSIRO Publishing.

Kusnandar, Padmaningrum, D., Rahayu, W., \& Widiyanto (2018), "Membangun Kelembagaan Ketahanan Pangan Lokal [Building Local Food Security Institutions]”, Surakarta: Aryhaeko Sinergi Persada.

Lema, T.Z., Tessma, S.A., \& Abebe, F.A. (2016), "Analysis of the Technical Efficiency of Rice Production in Fogera District of Ethiopia: A Stochastic Frontier Approach", Ethiopian Journal of Economics 26(2), 89108. [Online] Available: https://mpra.ub.uni-muenchen.de/77774/8/MPRA_paper_77774.pdf

Meeusen, W. \& Van den Broeck, J. (1977), "Efficiency Estimation from Cobb-Douglas Production Functions with Composed Error", International Economic Review 18(2), 435-444. DOI: 10.2307/2525757.

Murniati, K., Mulyo, J.H., Irham, \& Hartono, S. (2014), "Efisiensi Teknis Usahatani Padi Organik Lahan Sawah Tadah Hujan di Kabupaten Tanggamus, Propinsi Lampung [The Technical Efficiency of Organic Rice Farming in Rainfed Rice Field in Tanggamus Regency, Lampung Province]", Jurnal Penelitian Pertanian Terapan 14(1), 31-38. DOI: 10.25181/jppt.v14i1.139.

Myint, T. \& Kyi, T. (2005), “Analysis of Technical Efficiency of Irrigated Rice Production System in Myanmar”, 
Conference on International Agricultural Research for Development, Stuttgart-Hohenheim, October 11-13, 2005. [Online] Available: http://www.tropentag.de/2005/abstracts/full/126.pdf

Nuraini, C., Darwanto, D.H., Masyhuri, \& Jamhari (2016), "Model Kelembagaan pada Agribisnis Padi Organik Kabupaten Tasikmalaya [The Institutional Model for Organic Rice Agribusiness in Tasikmalaya Regency]", Jurnal Agraris 2(1), 10-16. DOI: https://doi.org/10.18196/agr.2121

Prayoga, A. (2010), "Produktivitas dan Efisiensi Teknis Usahatani Padi Organik Lahan Sawah [Productivity and Technical Efficiency of Organic Rice Field Farming]”, Jurnal Agro Ekonomi 28(1), 1-19. DOI: 10.21082/jae.v28n1.2010.1-19.

Scott, W.R. (2008), "Institutions and Organizations: Idea and Interest", California: Sage Publications.

Sudrajat, I.S. (2018), "Pengaruh Faktor-faktor Sosial Ekonomi dalam Efisiensi Usahatani Padi Organik di Kabupaten Boyolali, Jawa Tengah [Effect of Socio-Economic Factors on Efficiency of Organic Rice Farming in Boyolali, Central Java]. Unpublished Doctoral Dissertation, Sebelas Maret University of Surakarta, Indonesia.

Sudrajat, I.S. (2019), "Effect of Management Factor on Stochastic Frontier Production of Organic Rice Farming in Indonesia", Global Journal of Agricultural Research 7(1), 23-33. [Online] Available: https://www.eajournals.org/wp-content/uploads/Effect-of-Management-Factor-on-Stochastic-FrontierProduction-of-Organic-Rice-Farming.pdf

Sudrajat, I.S., Rahayu, E.S., Kusnandar, \& Supriyadi (2017), "Effect of Social Factors in Stochastic Frontier Profit of Organic Rice Farming in Boyolali”, Bulgarian Journal of Agricultural Science 23(4), 551-559. [Online] Available: https://www.agrojournal.org/23/04-05.pdf

Sudrajat, I.S., Rahayu, E.S., Supriyadi, \& Kusnandar (2018), "Effect of Institution on Production Cost Efficiency of Organic Rice Farming in Indonesia”, DLSU Business and Economics Review 28(1), 166-175. [Online] Available:

https://www.researchgate.net/publication/332172455_Effect_of_institution_on_production_cost_efficiency of organic rice farming in Indonesia/citation/download

Syahyuti (2004), "Model Kelembagaan Penunjang Pengembangan Pertanian di Lahan Rawa Lebak [Institutional Models Supporting Agricultural Development in the Rawa Lebak Land]", Workshop Nasional Pengembangan Lahan Rawa Lebak di Banjarbaru dan Kandangan, Kalimantan Selatan, October 11-12, 2004, pp 26-39. [Online] Available: http://pse.litbang.pertanian.go.id/ind/pdffiles/monograph_25_2004_2.pdf

Utama, S.P. (2003), "Kajian Efisiensi Teknis Usahatani Padi Sawah pada Petani Peserta Sekolah Lapang Pengendalian Hama Terpadu (SLPHT) di Sumatera Barat [Technical Efficiency Assessment of Lowland Rice in Farmers Participating in Integrated Pest Control Field Schools (SLPHT) in West Sumatra]", Jurnal Akta Agrosia 6(2), 67-74. [Online] Available: http://repository.unib.ac.id/7881/1/B4\%20Satria.pdf

Wihastuti, W., Sujaya, D.H., \& Hardiyanto, T. (2017), “Analisis Usahatani Padi Organik: Studi Kasus pada Kelompok Tani Kelapa Herang, Desa Setiawaras, Kecamatan Cibalong, Kabupaten Tasikmalaya [Analysis of Organic Rice Farming: Case Study in Kelapa Herang farmer group, Setiawaras Village, Cibalong District, Tasikmalaya Regency]", Jurnal Ilmiah Mahasiswa Agroinfo Galuh 4(3), 388-395. DOI: http://dx.doi.org/10.25157/jimag.v4i3.826

Yotopoulus, P.A. \& Nugent, J.B. (1976), "Economic of Development Empirical Investigation", New York: Harper \& Row Publisher.

\section{Biodata of the Author:}

Ignatius Suprih Sudrajat was born in Kebumen, Central Java, Indonesia on July 25, 1962. He is a researcher, senior lecturer and head of study program at Department of Agribusiness, Faculty of Agriculture, University of Sarjanawiyata Tamansiswa Yogyakarta, Indonesia. He obtained a PhD degree at Graduate School, Department of Agricultural Science, Sebelas Maret University of Surakarta, Indonesia in 2018. His research major field focuses on organic farming, agribusiness management, and environment. His mobile phone number: +62-8139228-4005 and e-mail address: suprihsudrajat@gmail.com. 